\title{
Ethics in Advertising - An Indian Perspective
}

\author{
Lovedeep Singh Sidhu ${ }^{1}$, Jyoti Sharma ${ }^{2}$, Shiny ${ }^{3}$, Shivani $^{4}$ \\ Assistant Professor at Shaheed Bhagat Singh State Technical Campus, Ferozepur City 1,2,3,4
}

\begin{abstract}
Advertising, using media as its vehicle, is a pervasive, powerful force shaping attitudes and behavior in today's world. At times it goes beyond the traditional role of 'fair and truthful' information and portraits obscene, undesirable and unethical scenes giving a detrimental result especially on the young population of the society. The ethical aspect of Indian advertisement is extremely important for restoration of our Indian culture, norms, ethics and heritage.
\end{abstract}

Keywords: Advertising, Obscene, Unethical, culture

\section{INTRODUCTION}

The Indian advertising industry is talking business today. It has evolved from being a small-scale business to a fullfledged industry. It has emerged as one of the major industries and tertiary sectors and has broadened its horizons be it the creative aspect, the capital employed or the number of personnel involved. Indian advertising industry in very little time has carved a niche for itself and placed itself on the global map.

Indian economy is on a boom and the market is on a continuous trail of expansion. With the market gaining grounds, Indian advertising has every reason to celebrate. Businesses are looking up to advertising as a tool to cash in on lucrative business opportunities. Growth in business has lead to a consecutive boom in the advertising industry as well.

\section{WHAT IS ETHICS?}

Ethics means "Good Conduct" or "Conduct which is right in view of the society and the time period". By common consent, various modes of behavior and conduct are viewed as "good" or "bad".

In other word, we can say that Ethics are moral principles and values that govern the actions and decisions of an individual group. Ethics is a choice between good and bad, between right and wrong. It is governed by a set of principles of morality at a given time and at a given place and in a given society.

\section{ETHICS IN ADVERTISING}

Advertising has ethical value. The mixing of Art and facts in advertising communication are subservient to ethical principles. In today's competitive and buyer's market, advertisements have to be truthful and ethical. If an advertisement is misleading, the credibility of the organization is lost. To view the truth in advertisement, it has to be seen from to consumer's point of view rather than from legal point. The advertising industry has been frequently criticized for putting out misleading or exaggerated claims in respect of product, goods and services advertised.

\section{GROWTH OF ADVERTISING INDUSTRY IN INDIA}

The Indian Media \& Entertainment (M\&E) industry is the fastest growing industry followed by China (14 per cent), Russia (12 per cent) and Brazil (11 per cent) as is projected to grow at 17 per cent compounded annual growth rate (CAGR) between 2012 and 2016. Its various segments -film; television, animation, print and Out-ofhome advertising $(\mathrm{OOH})$ among others-have witnessed remarkable growth in the past few years.

The Indian M\&E industry is expected to continue its strong growth momentum over 2012-2017 to reach an overall revenue of 2,245 billion INR at a CAGR of about $18 \%$. Television, the largest E\&M sector, is expected to grow at about 18\% CAGR over 2012-2017, driven by growth in subscription payment and advertising revenues. The entire M\&E landscape is witnessing a shift; thanks to cable digitization, wireless broadband penetration, increasing direct-to-home (DTH) penetration, digitization of film distribution and growing internet usage. Overall, the industry is expected to register a Compounded Annual Growth Rate (CAGR) of 15 percent to touch Rs 1,45,700 crore by 2016

\section{ADVERTISING REGULATION - INDIAN PERSPECTIVE}

The Advertising Standards Council of India

The Advertising Standards Council of India (ASCI), established in 1985, is committed to the cause of SelfRegulation in Advertising, ensuring the protection of the interests of consumers. ASCI was formed with the support of all four sectors connected with Advertising, viz. Advertisers, Advertising Agencies, Media (including Broadcasters and the Press) and others like PR Agencies, Market Research Companies etc. 


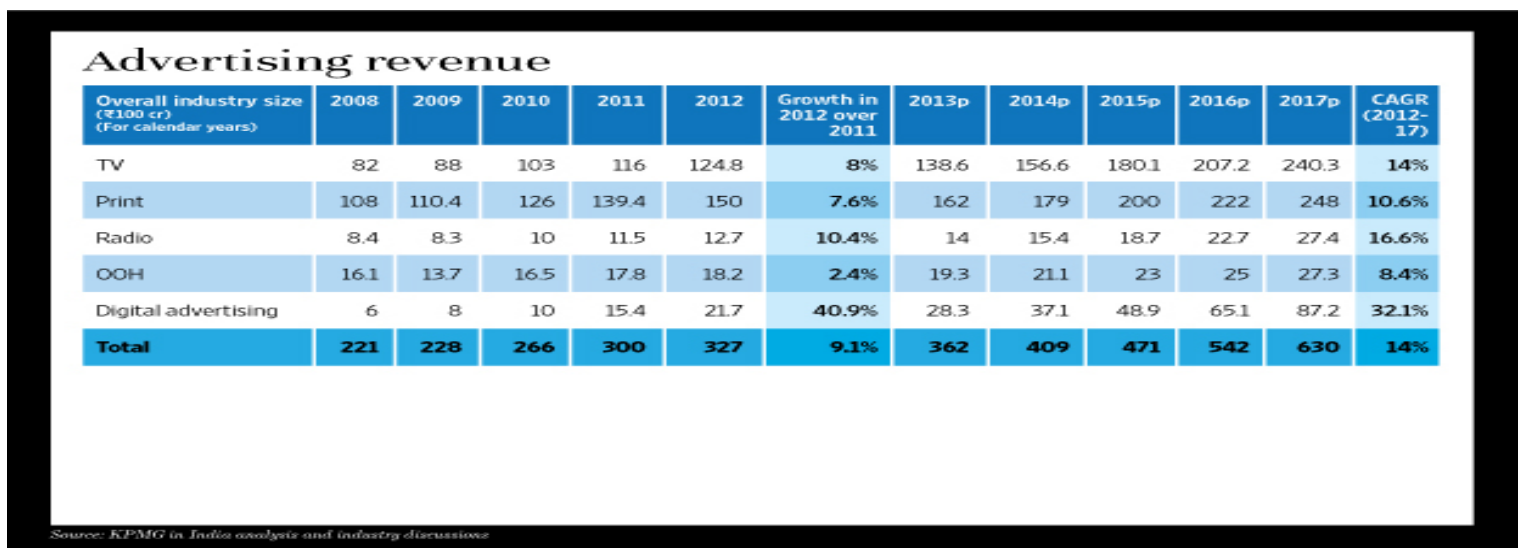

\begin{tabular}{|l|l|l|l|l|}
\hline SL. NO. & NAME OF COMPANY & $\begin{array}{l}\text { CORPORATE } \\
\text { OFFICE }\end{array}$ & $\begin{array}{l}\text { YEAR OF } \\
\text { ESTABLIS } \\
\text { HMENT }\end{array}$ & BUSINESS \\
\hline 1 & Ogilvy \& Mather Ltd & New York, USA & 1948 & Advertising, Marketing \\
\hline 2 & $\begin{array}{l}\text { GWT Hindustan Thompson } \\
\text { Associates }\end{array}$ & New York, USA & 1864 & $\begin{array}{l}\text { Advertisement \& } \\
\text { Marketing }\end{array}$ \\
\hline 3 & Rediffusion - DY\&R & New Delhi, India & 1985 & Advertisement \\
\hline 4 & Mudra Communications Ltd & $\begin{array}{l}\text { Ahmadabad, } \\
\text { Gujarat }\end{array}$ & $1980 \mid$ & $\begin{array}{l}\text { Advertising \& } \\
\text { Marketing }\end{array}$ \\
\hline 5 & McCann-Erickson India Ltd & U.S.A & 1930 & Advertising \\
\hline 6 & $\begin{array}{l}\text { Pressman Advertising and } \\
\text { Marketing Ltd }\end{array}$ & $\begin{array}{l}\text { Kolkata, West } \\
\text { Bengal }\end{array}$ & 1960 's & Advertising \\
\hline 7 & $\begin{array}{l}\text { FCB-Ulka Advertising Ltd } \\
\text { Corporate office }\end{array}$ & $\begin{array}{l}\text { Mumbai, } \\
\text { Maharashtra }\end{array}$ & 1961 & Advertising \\
\hline 8 & $\begin{array}{l}\text { RK Swamy BBDO Advertising } \\
\text { Ltd Corporate office }\end{array}$ & $\begin{array}{l}\text { Mumbai, } \\
\text { Maharashtra }\end{array}$ & 1973 & Advertising \\
\hline 9 & $\begin{array}{l}\text { Trikaya Grey Advertising (India) } \\
\text { Ltd }\end{array}$ & New York, U.S. & 1917 & $\begin{array}{l}\text { Advertising, } \\
\text { Entertainment, } \\
\text { Marketing }\end{array}$ \\
\hline
\end{tabular}

The Consumer Complaints Council is ASCI's heart and soul. It is the dedicated work put in by this group of highly respected people that has given tremendous impetus to the work of ASCI and the movement of self- regulation in the advertising.

\section{ASCI Codes}

The Advertising Standards Council of India (ASCI) (1985) has adopted a Code for Self-Regulation in Advertising. It is a commitment to honest Advertising and to fair competition in the market-place. It stands for the protection of the legitimate interests of consumers and all concerned with Advertising - Advertisers, Media, Advertising Agencies and others who help in the creation or placement of advertisements.

\section{ASCI have one overarching goal:}

To maintain and enhance the public's confidence in advertising. ASCI seek to ensure that advertisements conform to its Code for Self-Regulation which requires advertisements to be:
Honest Representations - Truthful and Honest to consumers and competitors.

$\square$ Non-Offensive to Public - Within the bounds of generally accepted standards of public decency and propriety.

Against Harmful Products/Situations - Not used indiscriminately for the promotion of products, hazardous or harmful to society or to individuals particularly minors, to a degree unacceptable to society at large.

Fair in Competition - Not derogatory to competition. No plagiarism.

\section{ASCI Guidelines}

Automotives \& Safety - Advertisers are encouraged to depict advertisements, in a manner which promotes safe practices, eg. Wearing of helmets and fastening of seatbelts, not using mobiles/cell phones when driving, etc.

Educational Institutions - Parents are known to make great personal sacrifices to enable their children to get the right education. A significant amount of advertising activity that is currently happening reflecting the vast variety of educational programs which are being offered. 
Foods \& Beverages - Advertising can have a positive following minimum size of lettering of "Supers" and its influence by encouraging a healthy, well balanced diet, holding time on screen for TV advertisements is required. sound eating habits and appropriate physical activity. Caution and care therefore should be observed in advertising of Foods \& Beverages especially ones containing relatively high Fat, Sugar and Salt.

\section{LAWS GOVERNING ADS}

Disclaimers in an Advertisement - "Supers" should be ASCI will not accept the ads which offends the provisions clearly legible and on TV advertisements should be held of the following Acts of Government of India or various long enough for the full message to be read by an average State Governments. viewer on a standard domestic TV set. Therefore

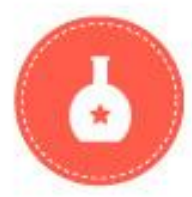

Drugs and Magic

Remedles Act, 1954

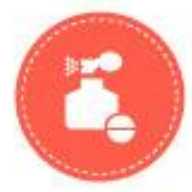

Drugs \& Cosmetics Act, 1940

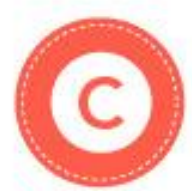

Copyright Act, 1957

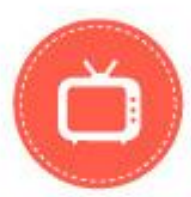

Cable Television Network Act

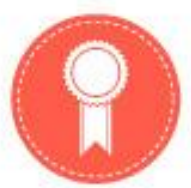

Emblems and Names Act, 1950

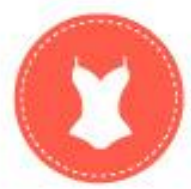

Indecent Representation of Women Act, 1986

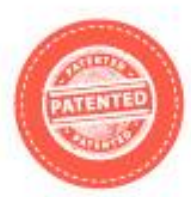

Patents Act, 1970

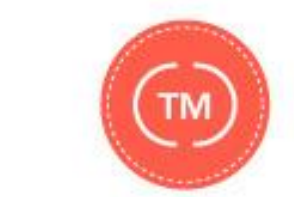

Trademarks Act, 1999

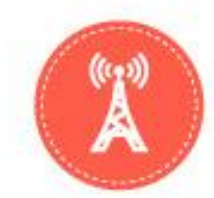

Prasar Bharti

Act, 1990

\section{ETHICAL ISSUES IN ADVERTISING:}

Advertising is a highly visible business activity and any lapse in ethical standards can often be risky for the company. Some of the common examples of ethical issues in advertising are given below:

- Vulgarity / Obscenity used to gain consumers' attention

- $\quad$ Misleading information and deception

- $\quad$ Puffery

- $\quad$ Stereotypes

- Racial issues

- Controversial products (e.g. alcohol, gambling, tobacco etc)

\section{SUSPENSION PENDING INVESTIGATION BY ASCI}

In exceptional circumstances, when it appears prima facie that an advertisement is in serious breach of the ASCI
Code and its continued transmission on/through/by any medium causes or has the effect of causing public harm and/or injury or its continuation is against public interest, then the ASCI would, pending investigation, forthwith direct the advertiser/the advertising agency/the media buying agency and the media concerned to suspend the advertisement. This decision of the suspension will be taken by the Chairman (or, in his absence, the Vice Chairman) of the ASCI in consultation with two members of the Consumer Complaints Council.

\section{DECISIONS BY ASCI FOR UNETHICS IN ADS}

December 2013: In September 2013, ASCI's Consumer Complaints Council (CCC) upheld complaints against 121 ads. Education, Health \& Personal Care categories continue to lead with the highest number of complaints. Complaints against the following ads were UPHELD 
International Advanced Research Journal in Science, Engineering and Technology

Vol. 2, Issue 5, May 2015

\begin{tabular}{|c|c|c|c|}
\hline $\begin{array}{l}\text { SL. } \\
\text { NO. }\end{array}$ & COMPANY & PRODUCT & COMPLAINT \\
\hline 1 & $\begin{array}{l}\text { Hindustan } \\
\text { Unilever Ltd }\end{array}$ & $\begin{array}{l}\text { Ponds Pure } \\
\text { White Face } \\
\text { Wash }\end{array}$ & $\begin{array}{l}\text { "Pond's pure white Face Wash } \\
\text { contains Activated-Carbon", } \\
\text { "This goes in the depth of your } \\
\text { skin and removes dirt and } \\
\text { pollution and saves you from } \\
\text { being affected by any skin } \\
\text { problems, get instant glow on } \\
\text { your skin", "Picture indicating } \\
\text { "premature aging, wrinkles". } \\
\text { These claims need to be } \\
\text { substantiated with necessary } \\
\text { support data }\end{array}$ \\
\hline 2 & $\begin{array}{l}\text { Reckitt Benckiser } \\
\text { (India) Ltd }\end{array}$ & $\begin{array}{l}\text { Veet Body } \\
\text { Moisturiser }\end{array}$ & $\begin{array}{l}8 \text { out of } 10 \text { women who tried } \\
\text { Veet Body Moisturiser agree } \\
\text { that only Veet Body } \\
\text { Moisturisers give longer lasting } \\
\text { smoothness", "New Veet } \\
\text { Moisturizer - its unique Pro } \\
\text { Minimise formula delays hair re- } \\
\text { growth which makes your skin } \\
\text { feel touchably smooth for a } \\
\text { longer time", "Women agree } \\
\text { that with Veet Body Moisturiser } \\
\text { you need to remove hair less } \\
\text { often" } \\
\text { These claims need to be } \\
\text { substantiated with necessary } \\
\text { support data. }\end{array}$ \\
\hline 3 & $\begin{array}{l}\text { Hindustan Unilever } \\
\text { Ltd(*) }\end{array}$ & $\begin{array}{l}\text { Sun Silk Perfect } \\
\text { Straight }\end{array}$ & $\begin{array}{l}\text { Ad shows - a girl packing/selecting all her } \\
\text { hair straightening equipment's and } \\
\text { another girl (her friend) tells her about a } \\
\text { shampoo that can keep the hair perfectly } \\
\text { straight after attending a gym session, } \\
\text { party or even in other situations. } \\
\text { After the use of the shampoo can every } \\
\text { form of hair type/texture remain perfectly } \\
\text { straight in any situation said? }\end{array}$ \\
\hline 4 & $\begin{array}{l}\text { Hindustan Unilever } \\
\text { Ltd }\end{array}$ & $\begin{array}{l}\text { Surf Excel Liquid } \\
\text { Detergent }\end{array}$ & $\begin{array}{l}\text { Ad depicts a child sprinkle ink on his white } \\
\text { shirt and face \& teeth. Ad is offensive and } \\
\text { negative in nature and children with } \\
\text { vulnerable minds could ape it with grievous } \\
\text { results. Ink is toxic, is it safe to allow the ink } \\
\text { to get into the child's mouth and the ink } \\
\text { even discolors his teeth? }\end{array}$ \\
\hline
\end{tabular}


International Advanced Research Journal in Science, Engineering and Technology

Vol. 2, Issue 5, May 2015

1

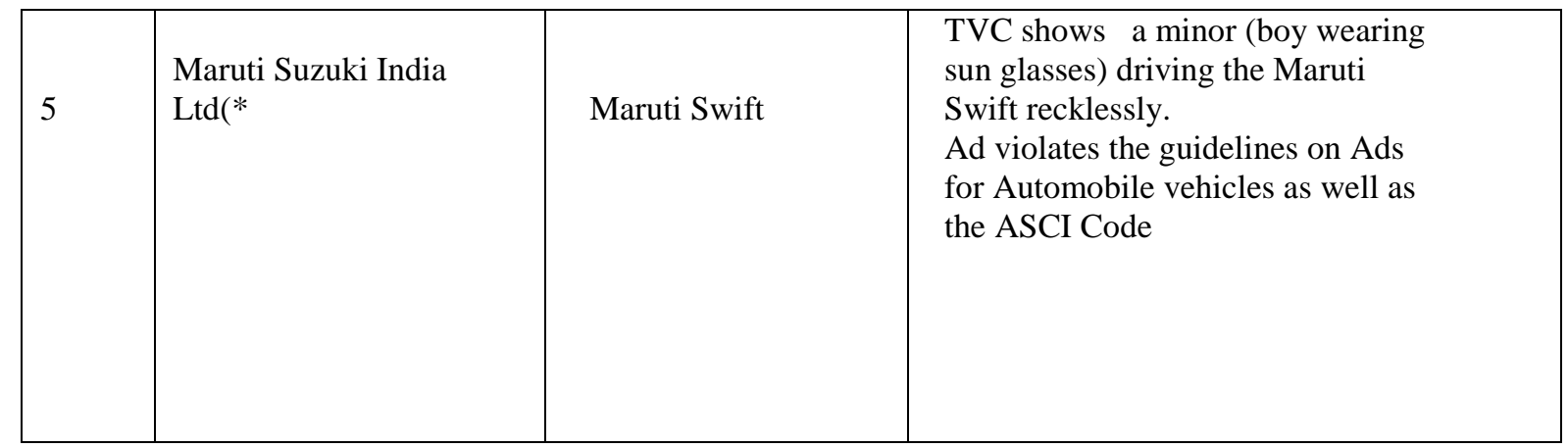

\section{CONCLUSION}

The ethical aspect of Indian advertisement is extremely important for restoration of our Indian culture and heritage. Indian culture is getting diluted by the western culture which influences our country to a great extent. Telecasting and publication of obscene, indecent advertisements clearly shows the percolation of western culture in India so, to save our culture, norms and ethics regulations of such unethical advertisements are extremely

essential. But today the numbers of unethical and obscene advertisements are escalating in numbers instead of decreasing. This clearly shows that implementation of the laws controlling advertisement is not properly done. The lacks of implementation of the laws are pouring in more and more unethical and obscene advertisements. Hence, proper implementation of the laws is highly required in our country.

\section{REFERENCES}

1.Brinkmann,j;2001b, On business Ethics, conflict measurement, and Conflict Management, working paper in progress

2 Callahan, J.C. eds. (1998) Ethical issues in professional Life. Oxford university press, New York/Oxford

3 Applabaum,A.(1999) Ethics for adversaries. Princeton university press, Princeton, $\mathrm{NJ}$

4 Lippke, R.L. (1995) Radical advertising Ethics.Rowman\&Littlefield, Lanham and London

5 http://www.businessphilosophy.co.uk/articles/ethics\&advertiising.pdf $6 \mathrm{htttp} ; / /$ smallbusiness.chron.com/list-ethical-legal-issues-advertising11466.html 